BIOORGANIC CHEMISTRY

\title{
Genotoxicity of a carcinogenic metabolite of benzo[a]pyrene for cells of neuronal differentiation lineage
}

\author{
A. V. Endutkin, V.S. Sidorenko ${ }^{1}$, D. O. Zharkov
}

Novosibirsk Institute of Chemical Biology and Fundamental Medicine, Siberian Branch of the Russian Academy of Sciences 8, Akademika Lavrentieva Ave., Novosibirsk, Russian Federation, 630090

${ }^{1}$ Department of Pharmacological Sciences, Stony Brook University Stony Brook, NY 11794-8651, USA

dzharkov@niboch.nsc.ru

\begin{abstract}
Aim. Benzo[a]pyrene-7,8-dihydrodiol-9,10-epoxide (BPDE) is the major metabolite of an environmental carcinogen, polycyclic aromatic hydrocarbon benzo[a]pyrene. The effects BPDE could have on neuronal cells progenitors are mostly uncharacterized. Methods. We have studied survival and morphology of cultured PC12 cells and mouse embryonic hippocampal neurons in the presence of BPDE. We have also used post-labeling to compare accumulation of BPDE adducts in cultured PC12 cells and fibroblasts. Results. The survival of cells and the level of adducts depended on the type of extracellular matrix to which the cells were attached. At tolerated BPDE doses, the adducts formed by this metabolite were efficiently repaired. In PC12 cells, BPDE toxicity and the level of adducts was generally lower than in fibroblasts. Conclusions. Overall, BPDE may be detrimental for developing neural tissue. However, the effects of BPDE on cells with the ability to differentiate into the neuronal lineage may depend on the cell microenvironment.
\end{abstract}

Keywords: DNA damage, DNA repair, genotoxicity, benzo[a]pyrene-7,8-dihydrodiol-9,10-epoxide, neuronal lineage.

Introduction. Benzo[a]pyrene (BP) is a well-known environmental mutagen and carcinogen. BP is metabolized by the consecutive action of cytochromes $\mathrm{P} 450$ (CYP1A1, CYP1B1) and epoxide hydrolase into several stereoisomers of benzo[ $a]$ pyrene-7,8-dihydrodiol9,10-epoxide (BPDE) [1], which then intercalate into DNA and react with purine moieties, predominantly with the exocyclic amino group of guanine [2]. Formation of BPDE adducts is cytotoxic and produces mutations and chromosome aberrations [3].

Although BP and BPDE action was extensively studied in human cells, only a limited number of cell lines have been characterized in this respect. In particular, little is known about the effects of these agents in cells of neuronal lineage, which may be important for assessing the environmental toxicity of BP. Here we analyze cyto-

(C) Institute of Molecular Biology and Genetics, NAS of Ukraine, 2012 toxic and genotoxic action of BPDE in two cell types capable of differentiation into neurons, PC12 rat pheochromocytoma cells and immature mouse embryonic hippocampal neurons.

Materials and methods. Cell isolation and growth. GM00637 cells (SV40-transformed human skin fibroblasts) and PC12 cells were obtained from the Coriell repository. All cell cultures were grown at $37^{\circ} \mathrm{C}$ in $5 \%$ $\mathrm{CO}_{2}$. GM00637 cells were grown in DMEM supplemented with $10 \%$ fetal calf serum, $10 \mathrm{U} / \mathrm{ml}$ penicillin and $100 \mathrm{mg} / \mathrm{ml}$ streptomycin. PC12 cells were grown in the same medium in suspension for $2-3$ days, passed through a $40-\mu \mathrm{m}$ filter, and seeded at $10^{5}$ cells/well into $24-w e l l$ plates precoated with either poly-D-lysine, mouse laminin, their 10:1 mixture, or rat tail collagen (all from «Sigma-Aldrich», USA). The cells were then grown in DMEM High Glucose supplemented with $10 \%$ horse serum, $5 \%$ fetal calf serum, penicillin and streptomycin 

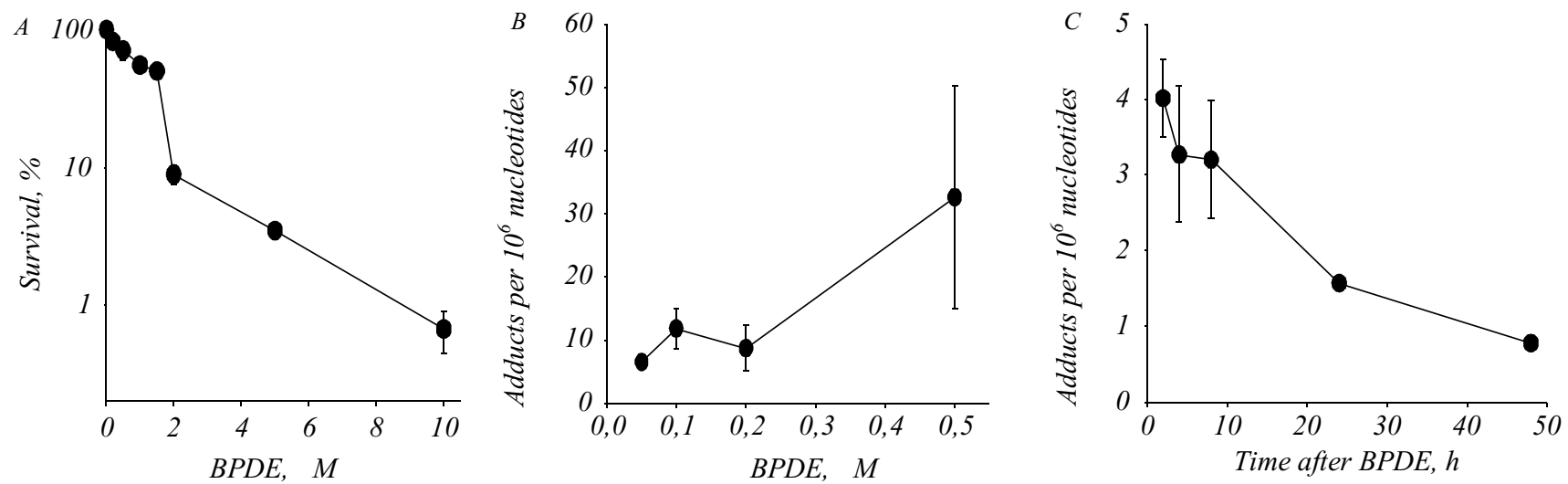

Fig. 1. $A$ - toxicity of BPDE for GM00637 cells (the cells were treated with $0-10 \mu \mathrm{M}$ BPDE for $14 \mathrm{~h}$, and their survival was determined by the ATP assay); $B$ - accumulation of BPDE adducts in DNA of GM00637 cells (the cells were treated with $0-0.5 \mu \mathrm{M}$ BPDE for $2 \mathrm{~h}$, and the adducts were analyzed by postlabeling); $C$ - removal of BPDE adducts from DNA of GM00637 cells (the cells were treated with $0.05 \mu \mathrm{M}$ BPDE for $2 \mathrm{~h}$, and the adducts were analyzed by postlabeling after $2-48 \mathrm{~h}$ in BPDE-free medium). Mean \pm SD of 3 independent experiments is shown

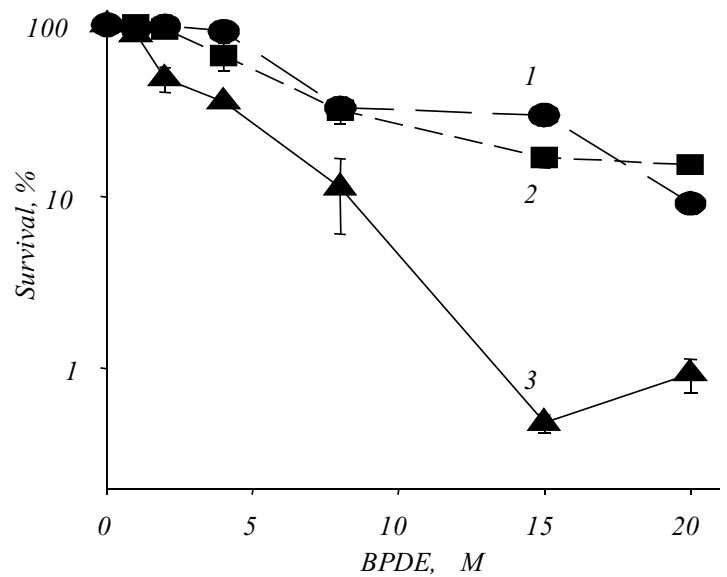

Fig. 2. Toxicity of BPDE for PC12 cells grown on the surfaces coated with poly-D-lysine (1), laminin (2) or their 10:1 mixture (3). The cells were treated with BPDE for $48 \mathrm{~h}$. Mean \pm SD of 3 independent experiments is shown

as above. The relative amount of live cells was determined by their ATP content using the ATP bioluminescent somatic cell assay kit («Sigma», USA). To obtain mouse embryonic hyppocampal neuron cultures, hippocampi from C57BL/6 E17.5 embryos were dissected, trypsinized, triturated in G3 medium (Neurobasal medium with B27 supplements, $25 \mathrm{M}$ glutamate, $0.5 \mathrm{mM}$ L-glutamine, and $10 \mathrm{~g} / \mathrm{ml}$ gentamycin sulfate, penicillin and streptomycin as above) and passed through a 40$\mu \mathrm{m}$ filter as described [4]. The cells were seeded at $10^{5}$ cells/well into 6-well plates precoated with a 10:1 mixture of poly-D-lysine and laminin in G3 medium. After $4 \mathrm{~h}$, the medium was changed, and after 4 days, glutamate was removed.
$B P D E$ treatment. BPDE (a mixture of trans $(+)$ and trans(-) stereoisomers) and BPDE-adducted oligonucleotides were a kind gift from Dr. Nicolas Geacintov (New York University) GM00637 or PC12 cells were grown to confluence, washed with PBS and treated by 1-20 $\mu \mathrm{M}$ BPDE (solution in DMSO) for the indicated time in the appropriate medium free of serum. If necessary, cells were then washed and transferred for the specified amount of time into serum-free, BPDE-free medium. For the control, the cells were grown without BPDE in DMEM, DMEM with serum, or DMEM with $2.5 \%$ DMSO. Mouse embryonic hyppocampal neurons were used at day 5 and treated with $10 \mu \mathrm{M}$ BPDE for $24 \mathrm{~h}$.

Adduct quantitation by postlabeling. DNA was isolated from BPDE-treated cells using the DNeasy Blood and Tissue kit («Qiagen», USA). 5-20 $\mu$ g of DNA was hydrolyzed overnight at $37{ }^{\circ} \mathrm{C}$ with a mixture of snake venom phosphodiesterase and micrococcal nuclease, and then for $1 \mathrm{~h}$ at $37^{\circ} \mathrm{C}$ with $\mathrm{P} 1$ nuclease as described [5]. The hydrophobic deoxynucleoside-BPDE adducts were extracted into butanol and phosphorylated with $10 \mathrm{U}$ OptiKinase («Affymetrix», USA) and 7.5 MBq $\left[\gamma-{ }^{32} \mathrm{P}\right]-$ ATP. The reaction mixtures were separated by electrophoresis in $30 \%$ non-denaturing polyacrylamide gels [5], which were visualized and quantified by phosphorimaging using Molecular Dynamics Storm 860 Imager. To quantify the adducts, a calibration curve was built using synthetic oligonucleotide standards containing a single BPDE adduct (5'-TCTTCTTCTGTXCYCTCTT CTTCT-3'; $X=\mathrm{G}$ or $\operatorname{trans}(-) \mathrm{G}-\mathrm{BPDE}, Y=\operatorname{trans}(+) \mathrm{A}-$ $\mathrm{BPDE}$ or $\mathrm{A})$ treated in the same way. 

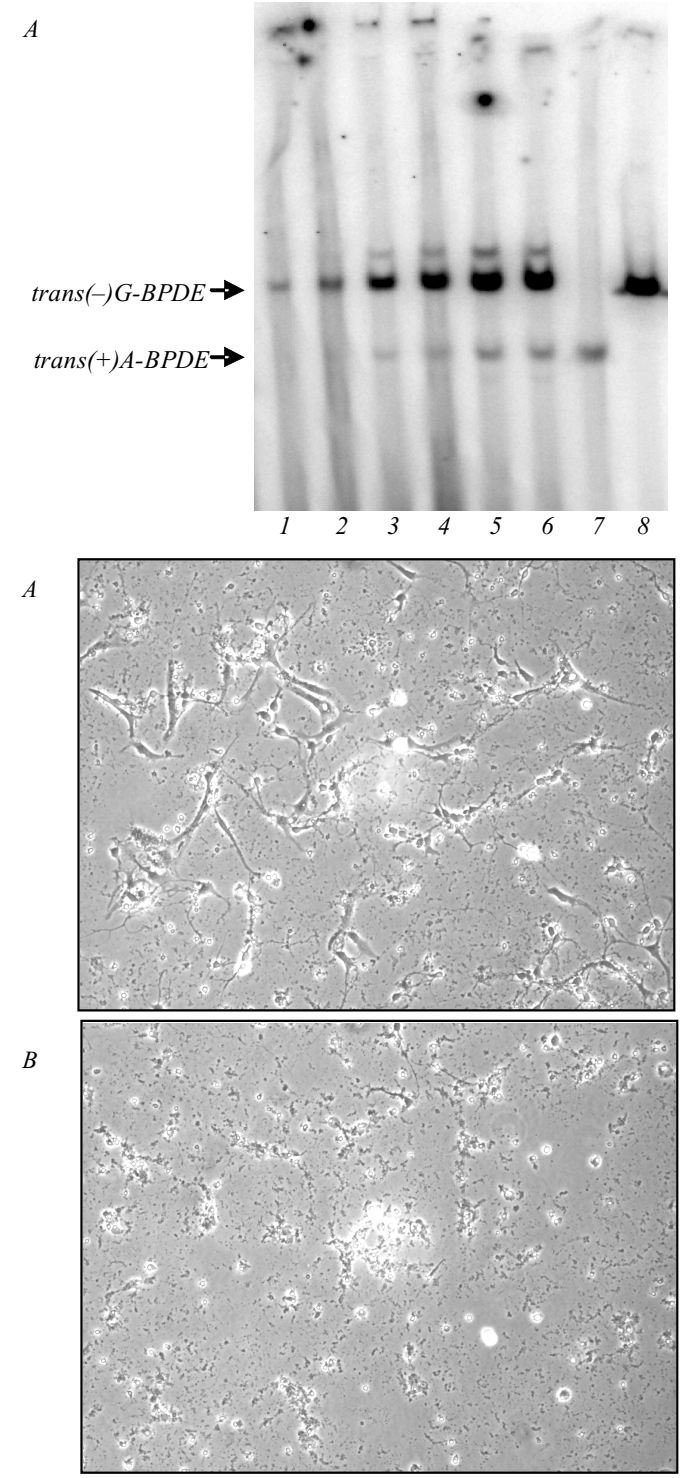

Fig. 4. Morphology of mouse emryonic hippocampal neurons after BPDE treatment: $A$-no BPDE; $B-10 \mu \mathrm{M}$ BPDE for $24 \mathrm{~h}$. Phase contrast microphotographs with $150 \times$ magnification are shown

Results and discussion. BP has to be metabolized to manifest its genotoxic properties. As cells can differ significantly in their ability to activate BP, we have utilized its ultimate metabolite, BPDE, to study its effect on cells. As model cells of neuronal lineage, we have used PC12, rat pheochromocytoma cells that acquire sympathetic neuron-like morphology upon treatment with nerve growth factor [6], and immature neurons derived from mouse embryo hippocampus [4]. Immortalized human fibroblasts (GM00637) were used as control cells.

Both GM00637 and PC12 cells were killed by BPDE in a dose-dependent manner (Fig. 1, A, Fig. 2). How-
Fig. 3. Postlabeling assay for BPDE adducts: $A$-gel showing the accumulation of adducts in PC12 cells grown on collagen and treated with 0.05 (1), $0.1(2), 0.2(3), 0.5(4), 1.0$ (5), and 2.0 mM BPDE (6). Lane 7, $\operatorname{trans}(+) \mathrm{A}-\mathrm{BPDE}$ standard; lane 8, $\operatorname{trans}(-) \mathrm{G}-\mathrm{BPDE}$ standard; $B-$ accumulation of BPDE adducts in DNA of PC12 cells. The cells were treated with $0-1 \mu \mathrm{M}$ BPDE for $2 \mathrm{~h}$, and the adducts were analyzed by postlabeling. Mean $\pm \mathrm{SD}$ of 3 independent

ever, PC12 cells were generally more resistant to BPDE than fibroblasts: while the survival of the latter was $\sim 10 \%$ even at $2 \mu \mathrm{M}$ BPDE and $<1 \%$ at $10 \mu \mathrm{M}$ BPDE, the survival of PC12 was compromised to $10 \%$ at $10-20 \mu \mathrm{M}$ BPDE depending on the growth conditions.

Interactions of cells with extracellular matrix in living tissues can significantly influence the outcomes of cellular stress $[7,8]$. PC12 cells normally require extracellular matrix coating to attach efficiently to plastic surfaces. We have found that the nature of this matrix affects survival of PC12 cells after BPDE treatment (Fig. $2)$. The cells showed little difference in survival when growing on poly-D-lysine or laminin but were more sensitive when grown attached to the poly-D-lysine: laminin 10:1 mixture (Fig. 2) or collagen (not shown).

To compare the amounts of BPDE-induced DNA damage in PC12 cells and fibroblasts, we have used the postlabeling assay (Fig. 3, A) to determine the level of BPDE adducts at doses when most treated cells are alive (less than $0.5-1 \mu \mathrm{M}$ BPDE). The levels of trans(-)G-BPDE in cells of both types increased in a dose-dependent manner (Fig. 1, B, Fig. 3, B), but PC12 cells always accumulated less adducts than fibroblasts did. After withdrawal of BPDE, the adducts were rapidly cleared from the cells' DNA (Fig. 1, C), consistent with the known efficient repair of this type of damage [9].

Finally, we have studied the effects of BPDE on mouse embryo hippocampal neurons. As the amount of cells that could be obtained was insufficient for reliable adduct or survival analysis, we have studied the morphology of the neurons after their attachment to the extracellular matrix-coated surface. After six days postplating in the absence of BPDE, many cells formed well-defined bodies and extended neurites, some of 
which even start to make connections (Fig. $4, A$ ). In contrast, when during the last $24 \mathrm{~h}$ the cells were treated with BPDE, the observed cells were small, rounded or irregular in shape, lacking processes, and it is likely that most of them were dead or dying.

Conclusions. Our data indicate that BPDE is cytotoxic and genotoxic for cells of neuronal differentiation lineage, and thus BP may be detrimental for developing neural tissue. However, the effects of BPDE on these cells may be modulated by the cells' microenvironment, including the extracellular matrix with which they interact.

Acknowledgements. This work was supported by RAS Presidium (Molecular and Cellular Biology, N 6.14), RFBR (10-04-91058, 11-04-00807), Russian Ministry of Science and Education (14.740.11.1195), and OPTEC Fellowship (58/11 KC) to A. E. We thank Drs Kathleen Dickman and Stella Tsirka and Ms Jillian Cypser (Stony Brook Uni- versity) for valuable discussion and technical assistance.

\section{А. В. Сндуткін, В. С. Сидоренко, Д. О. Жарков}

Генотоксичність канцерогенного метаболіту бензо $[a]$ пірену в клітинах нейрональної гілки диференціювання

Резюме

Мета. Бензо[а]пірен-7,8-дигідродіол-9,10-епоксид (ВРDE) - основний метаболіт канцерогенного поліциклічного ароматичного вуглеводню бензо[а]пірену. Вплив ВРDE на попередники нервових клітин практично не охарактеризовано. Методи. Вивчено виживаність і морфологію клітин РС12 та ембріональних гіпокампальних нейронів миші в культурі за присутності BPDE. Методом електрофорезу радіоактивно мічених нуклеотидів проаналізовано накопичення адуктів ВPDE у культивованих клітинах PC12 $i$ фібробластах. Результати. Виживаність клітин і рівень адуктів залежать від типу позаклітинного матриксу, до якого прикріплюються клітини. За сублетальних доз ВРDE спостерігається ефективна репарація адуктів, утворених иим метаболітом. Для клітин РC12 токсичність і рівень адуктів BPDE виявилися нижчими, ніж для фібробластів. Висновки. У цілому ВРDЕ може поруиувати нормальний розвиток нервової тканини, однак вплив BPDE на клітини, здатні до диференціювання по нейрональній гілиі, скоріш за все, залежить від їхнього мікрооточення.

Ключові слова: пошкодження ДНК, репарація, генотоксичність, бензо[а]пірен-7,8-дигідродіол-9,10-епоксид, нейрональна гілка.

\section{А. В. Ендуткин, В. С. Сидоренко, Д. О. Жарков}

Генотоксичность канцерогенного метаболита бензо[ $[a]$ пирена в клетках нейрональной ветви дифференцировки

Резюме

Цель. Бензо[а]пирен-7,8-дигидродиол-9,10-эпоксид (ВРDE) - основной метаболит канщерогенного полициклического аромати- ческого углеводорода бензо[а]пирена. Влияние ВPDE на предшественники нервных клеток практически не охарактеризовано.

Методы. Изучены выживаемость и морфология клеток РС12 и эмбриональных гиппокампальных нейронов мыши в культуре в присутствии ВPDE. Методом электрофореза радиоактивно меченных нуклеотидов проанализировано накопление аддуктов BPDE в культивируемых клетках РC12 и фибробластах. Результаты. Выживаемость клеток и уровень аддуктов зависят от типа внеклеточного матрикса, к которому прикрепляются клетки. При сублетальных дозах ВРDЕ наблюдается эффективная репарация аддуктов, образуемых этим метаболитом. Для клеток РС12 токсичность и уровень аддуктов ВРDЕ оказались ниже, чем для фибробластов. Выводы. В иелом, ВРDЕ может нарушать нормальное развитие нервной ткани, однако влияние BPDE на клетки, способные к дифференцировке по нейрональной ветви, может зависеть от их микроокружения.

Ключевые слова: повреждение ДНК, репарация, генотоксичность, бензо[а]пирен-7,8-дигидродиол-9,10-эпоксид, нейрональная ветвь.

\section{REFERENCES}

1. Jiang H., Gelhaus S. L., Mangal D., Harvey R. G., Blair I. A., Penning T. M. Metabolism of benzo[a]pyrene in human bronchoalveolar H358 cells using liquid chromatography-mass spectrometry // Chem. Res. Toxicol.-2007.-20, N 9.-P. 1331-1341.

2. Cosman M., de los Santos C., Fiala R., Hingerty B. E., Ibanez V., Luna E., Harvey R., Geacintov N. E., Broyde S., Patel D. J. Solution conformation of the (+)-cis-anti-[BP]dG adduct in a DNA duplex: Intercalation of the covalently attached benzo[a]pyrenyl ring into the helix and displacement of the modified deoxyguanosine // Biochemistry.-1993.-32, N 16.-P. 4145-4155.

3. Arce G. T., Allen J. W., Doerr C. L., Elmore E., Hatch G. G., Moore M. M., Sharief Y., Grunberger D., Nesnow S. Relationships between benzo(a)pyrene-DNA adduct levels and genotoxic effects in mammalian cells // Cancer Res.-1987.-47, N 13.-P. 33883395.

4. Rogove A. D., Tsirka S. E. Neurotoxic responses by microglia elicited by excitotoxic injury in the mouse hippocampus // Curr. Biol.-1998.-8, N 1.-P. 19-25.

5. Shibutani S., Kim S. Y., Suzuki N. ${ }^{32} \mathrm{P}$-postlabeling DNA damage assays: PAGE, TLC, and HPLC // Methods Mol. Biol.-2006.314.-P. 307-321.

6. Greene L. A., Tischler A. S. Establishment of a noradrenergic clonal line of rat adrenal pheochromocytoma cells which respond to nerve growth factor // Proc. Natl Acad. Sci. USA.-1976.-73, N 7.-P. 2424-2428.

7. Cordes $N$. Integrin-mediated cell-matrix interactions for prosurvival and antiapoptotic signaling after genotoxic injury // Cancer Lett.-2006.-242, N 1.-P. 11-19.

8. Jean C., Gravelle P., Fournie J. J., Laurent G. Influence of stress on extracellular matrix and integrin biology // Oncogene.-2011.30, N 24.-P. 2697-2706.

9. Hess M. T., Gunz D., Luneva N., Geacintov N. E., Naegeli H. Base pair conformation-dependent excision of benzo[a]pyrene diol epoxide-guanine adducts by human nucleotide excision repair enzymes // Mol. Cell. Biol.-1997.-17, N 12.-P. 7069-7076. 